\title{
Institutions and social change: a case study of the South African National AIDS Council
}

\author{
Theodore Powers \\ The Human Economy Project, Faculty of Humanities, University of Pretoria, Private Bag x20, Hatfield, Pretoria, 0028, South Africa \\ powers.theodore@gmail.com
}

\begin{abstract}
Institutions play an important role in the success or failure of social models, as they promote or limit particular political and economic activities. Central to this point is the understanding that institutions and traditions are in a constant state of flux. Taken in this light, state and non-state institutions are continually being 're-invented' to reflect a particular society's changing economic, political and cultural division of power. Immanent in this constant process of change is the possibility of transforming formal political institutions to more closely reflect the needs of human beings. The South African National AIDS Council provides a useful case study to illuminate how non-state social alliances can transform state institutions to reflect the needs of society Through the mobilisation of non-state and community-based organisations, the South African HIV/AIDS movement successfully influenced the South African government to expand the public health response to the HIV/AIDS epidemic.
\end{abstract}

Keywords: HIV/AIDS, globalisation, institutions, social movements, social change, South Africa

\section{Introduction}

The South African HIV/AIDS epidemic has occupied an exceptional position in the academic literature due to its comparatively late emergence on the African continent and the contentious politics that developed in response to its spread. The epidemic grew exponentially during the 1990s and with it a political debate over HIV/AIDS treatment between the South African HIV/AIDS movement and a faction of the ruling party. The prolonged political contestation over treatment access focused on HIV/AIDS policy and the state institutions that controlled its dissemination (Powers 2013). Within this context, the South African HIV/AIDS movement influenced national policy and the composition of state institutions through extended negotiation and direct action. This process entailed HIV/AIDS activists challenging the international pricing structure for antiretroviral drugs and government inaction on treatment access through the support of transnational networks of HIV/AIDS activists and international health institutions (Grebe 2011).

The success of the South African HIV/AIDS movement created institutional conditions that now sustain human life in South Africa. A central component of this process was the negotiated transformation of the South African National AIDS Council. Based largely on the work of this restructured institution, South Africa began offering free universal treatment to the public in 2010, quadrupled its spending on HIV/AIDS from 2006-201 1, and now boasts the largest HIV/AIDS program in the world (UNAIDS 201 3:61). The historical process through which this was achieved is significant for the object of this article: to explore the methodological and theoretical relevance of the human economy approach to institutions and social change in the contemporary phase of globalisation.

\section{Globalisation, institutions and social change}

A common theoretical focus in recent anthropological research is the social, political and economic effects associated with the current era of globalisation. The HIV/AIDS epidemic offers a useful means to understanding the socioeconomic entailments of the contemporary phase of globalisation and the societal responses to these conditions. Altman (2001) contends that the epidemic can be linked to several of the defining criteria of globalisation in the late $20^{\text {th }}$ century, including increased population movement, growing connectivity between the world's regions, the social conditions created by the imposition of fiscal austerity by international financial organisations, and the emergence of transnational initiatives to limit its spread. This has led some to characterise AIDS as a disease of the global system (Baer et al. 2003).

One approach to understanding this period has been to invoke the concept of 'neoliberalism' to explain the new cross-cultural commonalities. This theoretical positioning ties rising levels of social inequality, the retreat of the state and the rise of elite power via the implementation of free-market economic policies (Comaroff and Comaroff 2001, Schneider and Susser 2003, Dumenil and Levy 2005, Harvey 2005). The effects of these policies include the privatisation of social services, steep cuts to the welfare state and an expanded role of non-governmental organisations (NCOs) to fill the gaps created by these cuts in the social safety net (Gill 2000). Critical in this process has been the impact of unfettered finance capital in fomenting a 'race to the bottom' in global labor standards and corporate taxation levels. Close attention to global shifts in production highlight that this decline in wage levels has corresponded with the feminisation of low wage industrial labor, particularly in East Asia (Eisenstein 2010). While this literature has highlighted the social impact of contemporary globalisation, it has done so from a top-down perspective. Broadly speaking, the spread of transnational politico-economic norms has been traced from international financial institutions to their social effects on 'developing' countries.

Another important aspect of this historical period is the emergence of NGOs as increasingly significant political actors. This is particularly the case in the Global South, where neoliberal politico-economic norms were first implemented in the early 1980 s. In 
enabled the success of this mode of production. For Polanyi, the institutions of the state operated separately from the 'forms of integration' upon which society is reproduced. On this point, Polanyi was primarily concerned with the way in which reciprocity, redistribution and exchange governed economic life (Polanyi 1977:36). However the underlying insight is significant here: that the core principles that governed society differed from the abstract principles according to which state institutions operated.

The examination of the distance between social life and institutional practices also figures prominently in the work of Marcel Mauss. In an essay on primitive classification that was co-authored by his uncle, Emile Durkheim, Mauss (1963[ 1903]) lays out an understanding of social solidarity as emerging from shared classifications, which were seen as projections of social structure. Here the sacred is commensurable with these shared classifications, and draws its power then from shared experience, rather than centralized state institutions (Douglas 1986). As such, social change was an extension of self-expression expanding out towards society, rather than a top-down process dictated by politico-economic elites and the state institutions they controlled. Thus, Mauss' analysis points to the possibility of "building new groups and institutions alongside and on top of the old ones" (Hart 2009). This perspective is an important counterpoint to theories of social change predicated on producing a rupture with the past. Instead, Mauss saw that a pluralistic society could be reflected in institutional form. The incorporation of new and different activities into the formal sphere could then enable gradual social change. In other words, the relation between social life and state institutions carries with it the possibility of convergence.

On the basis of individual expression and group action, institutions are thus capable of acting as vehicles that enable existing modes of alternative social, economic and political activity. An analysis of state institutions should, therefore, examine the potential for institutional change to reflect the plurality of socio-economic organisation. A critical examination of the role of institutions in the extended political negotiations over South African HIV/AIDS policy and treatment contradicts some of the observed changes seen amongst developing states during the contemporary phase of globalisation. Rather than acting as passive conduits for transnational political and economic forces, South African state institutions played an active role in establishing national control over donor capital and the public sector response to the HIV/AIDS epidemic. For example, the National Development Agency was created to serve as an institutional mechanism that was capable of redirecting donor capital to fit the developmental criteria of the South African government (Powers 2012).

The restructuring of the South African National AIDS Council (SANAC) offers an example of how the South African HIV/AIDS movement transformed state institutions guiding the public health response to the epidemic. Through this process, the perspective of people infected and affected by the epidemic came to be included in the development of national policy. In the hybrid state-civil society institution, the ideas and concrete experiences of non-state actors contributed to changing South African society. In examining the policy development process within SANAC, an important issue to address is the relationship between lived experience and the type of input valued in the development of national policy norms. Following Mauss' conception of social change, one must ask whose input was valued, what kind of experiences were represented via their input and how the new policy then reflected particular experiences of the epidemic in South Africa.

The questions posed and conceptual positioning taken here grow out of an interdisciplinary attempt to understand social, institutional and economic activities that do not fit neatly into traditional categories such as capitalist or socialist. The Human Economy programme - on which this special issue is focused - grows out of international initiatives such as the alter-globalisation movement and gatherings such as the World Social Forum. Growing out of these meetings, academics and activists have sought to identify new principles and practices around which society might be organised. The human economy is one such venture. Rather than depend upon abstract ideals or models, the human economy programme promotes the observation and analysis of pre-existing modes of social, political and economic organisation (Hart 2009). Central to this initiative is the utilisation of anthropological research methods rooted in historical analysis. The goal of the project is to identify and analyse new and/or different forms of human organisation and their potential to change society. In the discussion that follows, the South African HIV/AIDS movement and the restructuring of the South African National HIV/AIDS Council will be analyzed with these considerations in mind.

\section{Methodology}

The data for this analysis was gathered over the course of five years. The methods employed for this project included indepth observation, participant observation, semi-structured interviews and informal interviews. In total, interviews were carried out with sixteen individuals involved in the civil society sectors of the South African National AIDS Council. The roles played by these participants included sectoral delegates, reference group members and researchers recruited to contribute to SANAC. One aim of these interviews was to understand the internal challenges to consultative process within civil society sectors. Another was to understand the relationship between state and non-state participants within SANAC. Although government delegates were contacted to participate in this research, none chose to take part. As will be discussed below, the divisive politics of HIV/AIDS in South Africa from 1999-2008 played an important role in this outcome.

\section{A brief history of HIV/AIDS politics in South Africa}

The South African HIV/AIDS epidemic emerged in the 1990s, coinciding with the negotiated transition out of apartheid. A divisive political debate on HIV/AIDS prevention and treatment between a faction of the ANC and HIV/AIDS activists ensued that led to international support for orthodox HIV/ AIDS science. Within this context, the South African HIV/ AIDS movement overcame political, economic and institutional barriers in order to increase access to treatment in the public health sector. From multinational corporations to negotiations with members of the ruling party, the HIV/AIDS movement engaged with a wide range of actors, organisations, and institutions across political scales. This social process led to the restructuring of SANAC and the opening of 
space for non-state actors to oversee and guide state policy implementation. Some have attributed the input of non-state actors on policy as due to the 'openness' of political institutions to formal political engagement (Makino 2009). However this perspective overlooks the role of HIV/AIDS activists, human rights lawyers and the gay rights movement in creating rights-based policy norms and institutional mechanisms that allowed for non-state participation (Heywood and Cornell 1998). As will be outlined below, this sustained political activism created the necessary preconditions for the South African HIV/AIDS movement to pressure the state into providing antiretroviral-based HIV/AIDS treatment.

The historical background to this period of sustained political action was governmental inaction to combat the epidemic in the late apartheid era. Despite evidence that HIV was present on the mines in 1982, little was done to stem the tide of infection. During the political transition the epidemic came to play a more prominent role. The African National Congress (ANC) worked with the National Progressive Primary Healthcare Network (NPPHN), human rights lawyers, non-governmental organisations and activists to create a policy platform to address the growing threat of HIV/AIDS. A rights-based approach to the epidemic was established with the National AIDS Plan (1994). This was based on the Charter of Rights on AIDS and HIV, developed in 1991 by human rights lawyers, gay men and health professionals (Heywood and Cornell 1998:65). Based upon the influence of the early HIV/AIDS movement, the political transition established institutional conditions that supported future activism.

Despite the establishment of a strong policy platform, the HIV/AIDS epidemic grew exponentially during the 1990s. Between 1990 and 1999, HIV prevalence in South Africa grew from $0.73 \%$ to 22.6\% (Gilbert and Walker 2002). The government struggled to implement the comprehensive National AIDS policy amidst the development of a new government structure and administration in South Africa (Schneider 2002). This transformation posed serious challenges to a coordinated response to the epidemic. From the reshaping of municipalities to the creation of new provinces, a democratic South Africa emerged during this time. The first democratic government faced many challenges during this time, but none posed as large a threat to the post-apartheid project of an 'African Renaissance' as the HIV/AIDS epidemic (Posel 2005).

The late 1990s saw this challenging situation exacerbated when leading members of the ANC questioned the link between HIV and AIDS. This 'AIDS dissident' position characterised HIV/AIDS treatment as toxic and unaffordable, challenged the representation of Africans as over-sexualised and questioned the political economy of the global pharmaceutical industry (Fassin 2007, Nattrass 2007, Gevisser 2007). A faction that supported this position emerged within the ruling party that included ANC members in positions of power in the Department of Health and President Thabo Mbeki. The obfuscation of HIV/AIDS science and delay in the adoption of anti-retroviral treatment (ART) prematurely ended the lives of some 330,000 South Africans (Chigwedere et al. 2008). The human toll of inaction led to the radicalisation of the HIV/ AIDS movement and the formation of the Treatment Action Campaign (TAC) in 1998. Initiated by former anti-apartheid activists, the TAC expanded the base of the HIV/AIDS movement by organising predominantly Black poor and working class South Africans. The TAC formed the leading edge of a campaign of direct political action against the ANC government and the global pharmaceutical industry.

The TAC's first major campaign sought to reduce the cost of AIDS treatment. The ability of antiretroviral drugs to prevent HIV transmission and extend the lives of people living with AIDS was established during the mid-1990s. However, the prices for these drugs were extremely high and patent- protected by the Trade-Related Intellectual Property Rights and Services (TRIPS) agreement of the World Trade Organization. Further, the ANC government had adopted the fiscally austere Growth, Employment and Redistribution (GEAR) macroeconomic strategy in 1996. This policy was a self-imposed version of the International Monetary Fund's notorious 'structural adjustment' programs (Bond 2005). Within this limited financial context, the ANC sought to access generically produced drugs through the drafting of the Medicines and Related Substances Control Amendment Act (1997). In response, multinational pharmaceutical corporations filed a legal challenge to the law and the United States government threatened to place South Africa on a watch list for sanctions.

While the ANC backed down from its stance against treatment access, the South African HIV/AIDS movement directly challenged the international pricing system for AIDS drugs. The TAC attacked multinational pharmaceutical corporations in a 'name and shame' campaign. In a civil disobedience act widely covered by global media, TAC activist Zackie Achmat imported 5,000 fluconazole pills from Thailand in October 2000. At this time the price of one pill was RI .78 in Thailand (\$0.25), while it cost RI24.84 in South Africa (\$18.10) (Soal 2000). This campaign led to significantly reduced costs for AIDS drugs in developing countries. The United States also relented on its threat, allowing South Africa to import generic medicines. In sum, the 'name and shame' campaign succeeded in lowering the cost of medicines, with some manufacturers reducing the cost of their medications by up to $95 \%$ of the patent-protected prices (Karon 2001).

While the cost barrier to treatment access was overcome, the control of key state institutions by members of the ANC's AIDS dissident faction limited the provision of ART in South Africa's public health sector. The TAC, Aids Law Project and other organisations associated with the South African HIV/AIDS movement challenged this inaction through legal cases, developing support for AIDS treatment within the ruling alliance and a civil disobedience campaign. The legal challenge over access to nevirapine for the prevention of mother-to-child transmission of HIV (PMTCT) led to a Constitutional Court victory for the HIV/AIDS movement. However the ANC did not implement this policy, leading to a civil disobedience campaign led by the TAC. During the course of this campaign, the South African HIV/AIDS movement cultivated ties with the Congress of South African Trade Unions (Cosatu), the South African Communist Party (SACP) and moderate elements within the ANC. On the basis of these strategic relationships, the AIDS dissident faction of the ANC was side-lined and ART became adopted as national policy in 2003.

While the struggle for treatment access appeared to have been won, the control of health institutions by the AIDS dissident faction led to further delays in the implementation of ART in South Africa's public health system. This led the South African HIV/AIDS movement to form a non-state oversight mechanism - the Joint Civil Society Monitoring Forum - and to threaten legal action against the government (TAC 2005). While the Department of Health relented and purchased ARVs, progress moved slowly in 
the accreditation of sites for distributing HIV/AIDS drugs (Nattrass 2008). Within this context, the South African HIV/AIDS movement cultivated a working relationship with the Deputy Minister of Health, Nozizwe Madlala-Routledge, and the Deputy President, Phumzile Mlambo-Ngcuka (Geffen 2010:71-2). When noted AIDS dissident and Minister of Health Manto Tshabalala-Msimang went on sick leave in late 2006, this created a window of opportunity to change the course of HIV/AIDS politics in South Africa.

In this political context, a restructuring of SANAC was led by the Deputy President. The TAC and other leading organisations in the South African HIV/AIDS movement were included in negotiations over the form and membership of the new body. The new SANAC would include a civil society co-chair on all major committees and an expanded civil society component that would incorporate feedback on policy development from non-governmental and community-based organisations throughout South Africa. The transformation of SANAC created a formal role for non-state forces in formal state institutions. Part and parcel of this process was the development of a new national HIV/AIDS policy that included hard targets for treatment availability, the National Strategic Plan for HIV/AIDS and STIs. As these processes unfolded simultaneously, the restructured SANAC became a vehicle for the development of the National Strategic Plan.

\section{SANAC, networks, and consultative policy development}

Initially created as a high-level inter-ministerial committee, through a combination of transnational influence and domestic political pressure SANAC was transformed into a joint state-civil society institution. The institution's hybrid structure enabled policy input for non-state actors and organisations. The form and focus of the restructured SANAC offer a fascinating example to think through the capacity of this new institutional form to serve as a basis for social change. The following description of institutional dynamics will focus on the $2007 / 08$ period, the formative era of the new SANAC.

One of the primary accomplishments of this period was the development of new PMTCT guidelines. This new policy was created at a meeting that included all civil society delegates to SANAC in October 2007. I was invited to attend this meeting as an observer. At the time, I had been conducting participant observation research with members of the TAC in the city of Cape Town. This research was carried out both in the Khayelitsha branch office, the Western Cape provincial office, and the TAC national office. The focus of my research at the time of this meeting was the implementation of the National Strategic Plan and SANAC's role in this process. The conference was titled the 'National Civil Society Conference on Implementing the National Strategic Plan'. In essence, this meeting pulled together all non-state SANAC participants in order to create a unified direction forward in the implementation of the new national HIV/AIDS policy.

At this conference, a working group of individuals that represented labour union, non-governmental organisations and community-based organisations worked with doctors and HIV/AIDS activists to develop new guidelines for PMTCT policy. The process of updating PMTCT guidelines highlighted the capacity of SANAC to incorporate ideas and input from a wide range of actors and organisations. The working group actively solicited input from all members, who painted a challenging picture of the public health response to the epidemic. However, not all working group members participated equally. The voice that dominated the working group was 'Steve', a nationally recognised paediatric AIDS doctor. I had met Steve prior to the National Civil Society conference through fieldwork in Johannesburg.

During an interview with Steve, he described his participation in the piloting of the ARV nevirapine in South Africa. As discussed above, the availability of nevirapine in the South African public health sector was an important victory for the South African HIV/AIDS movement in the extended political struggle for treatment access. Steve had been at the centre of this process, playing an active role in the court cases and receiving threats from the Department of Health for doing so. From the onset of the PMTCT group meeting at the National Civil Society conference, Steve had the attention and respect of those participating in the policy development process. As the meeting wore on, his combination of expert knowledge of the intricacies of PMTCT and the World Health Organization's updated policy recommendations separated him from the rest of the working group. As a note-taker for this meeting, I scrambled to correctly log scientific terminology and keep up with the pace of discussion. While the voices of nonexperts played a substantive role in the session, it was the person who was most familiar with policy and science that dominated the development of PMTCT guidelines. The fifteen guidelines developed by this working group were roughly based on updated recommendations from the World Health Organization. At the following meeting of SANAC's decision-making body - the plenary the Deputy President committed government to redrafting national PMTCT protocol within two weeks (Geffen 2007:81).

Subsequent interviews with researchers and others participating in the institution confirmed that the internal dynamics of the PMTCT working group were largely reflective of the policy development process within SANAC. More specifically, policy processes within the Council were focused around the opinions of policy experts and/or professionals. One example of this comes from a person that I interviewed involved with the SANAC's children's sector. 'David' was a part of the extended reference group, or a group of people working on issues related to a given sector from around South Africa. During our conversation, David explained how he had been chosen for a role in this working group. He had been invited to attend a SANAC meeting in March 2007 due to his role in coordinating HIV/AIDS program in schools throughout his province. A central aspect of David's work was to communicate the needs of these schools to members of parliament, and conversely, to communicate changes in government policy to those leading HIV/AIDS programs in schools. Based upon this policy expertise, David was asked to write a section of the draft National Strategic Plan relating to the needs of children in South Africa.

This tendency towards expertise was visible to others involved with SANAC. One education sector representative I interviewed had been involved in high-level provincial administration prior to a move to higher education. A representative from the women's sector whom I interviewed had a background in academic research rather than community organisation and mobilisation. 'Janice' relayed her frustration with this role and the lack of clear guidelines to conduct consultation, or even about what constituted a 'sector'. What was clear to Janice was what the South African HIV/AIDS movement had looked for in its representatives: 
But there's been a tension within SANAC between, on the one hand, an expressed desire that they want lots of people who are quite senior in different sectors to be the reps. And the fact that if you go high enough up, senior enough up, in any organisation, you're going to hit people who have very little time. [...] And it was expressed that they wanted that to get appropriate high-level input into the SANAC plenary.

Janice also discussed issues such as sufficient funding, the workload entailed with her role and difficulties in her working relationship with leading members of the South African HIV/ AIDS movement during the course of an extended interview. Another point of discussion for the analysis here was her discomfort with 'representing' women in South Africa. To what extend did she, as a researcher with academic training, represent all women in South Africa?

The critical question posed by Janice necessitates a broader consideration of how and why people became involved with SANAC. A useful example to discuss this issue was my conversation with 'Petra', another individual with an academic research background. Petra was affiliated with a South African national research institute and a South African university. She had conducted research on local and regional institutional mechanisms for coordinating the HIV/AIDS response in South Africa. During the course of an interview, Petra described how she had been recruited to participate in policy development within SANAC. Petra described how she had received a call from SANAC Deputy Secretary Mark Heywood on a Friday in early May 2008. During this call, the Deputy Secretary asked for a set of guidelines on provincial, district and local AIDS councils. The South African Deputy President had asked Heywood to provide this information to her by the following Monday. Petra worked with a researcher from the Centre for Municipal Research and Advice in producing these guidelines by that Sunday. As such, these terms of reference came from an academic researcher and an individual from a private consulting agency.

As was the case with several other individuals with whom

I spoke, the role of noted HIV/AIDS activist Mark Heywood was critical in the process of their recruitment and participation in SANAC. Heywood has a long and storied background as an activist. A former member of the Marxist Worker's Tendency of the ANC, Heywood joined the AIDS Law Project in 1994 and was a founding member of the TAC (Section27 2013 ). In this role of Deputy Secretary of SANAC, Heywood leaned heavily on the networks of HIV/AIDS and human rights activists that have influenced state policy since the political transition. As such, the composition of SANAC at this time must be understood as growing out of a sustained period of political mobilisation by non-state social forces. This network also incorporated the policy expertise of the nongovernmental sector and the specialised knowledge of academic researchers, medical doctors and private research consultancies. While it was possible for Heywood to influence state policy on the basis of this extended network, this was accomplished in an environment that was constrained by political, economic and institutional forces.

\section{Political, economic and institutional limits to SANAC}

The transformation of SANAC into a mechanism for nonstate policy input was limited by the political struggle over HIV/AIDS treatment, the economic limits imposed by South Africa's macroeconomic policy and the structure of the South African government. The major hurdle that the South African HIV/AIDS movement faced within SANAC was institutional intransigence by the government. Several civil society delegates relayed how SANAC meetings were cancelled, government officials did not attend meetings, and how government administrators would not fulfil their responsibility to provide support to the Council. One delegate referred to these practices as 'subterfuge', in reference to the continued influence of the ANC's AIDS dissident faction in the Department of Health.

For many of the civil society delegates I spoke to, the return of Minister of Health Manto Tshabalala-Msimang had ended the brief 'window of opportunity' within which SANAC was transformed. The institutional arrangements that were put into place after her return testified to this fact. Shortly after her return to office, Msimang was named as chair of the Resource Management Committee. Soon thereafter, noted AIDS dissident and Director General for Health Thami Mseleku was named chair of the Program Implementation Committee. Through these appointments, the AIDS dissident faction effectively controlled the flow of resources and oversight capabilities of SANAC (Powers 2012). This shift within the institutional control of SANAC was possible because the fine details of the restructuring had not been settled prior to the Minister of Health's return. This internal obstacle was overcome with the 'recall' of President Thabo Mbeki and removal of Tshabalala-Msimang as Minister of Health in September 2008. However it posed a significant challenge during the first year of the new SANAC's functioning.

Another important factor that restricted the impact of SANAC's policy input was limited financial support. After an initial outlay of R30 million, the Council had received little financial support from government (Khumalo and Berger 2008:67). Due to this, the support of transnational donor capital played an important role. In early 2008, the Bill and Melinda Gates Foundation provided a R6.3 million grant to SANAC $(\$ 900,000)$ through the Human Sciences Research Council. This research centre received the funding on behalf of SANAC, and the funds were used for research, sectoral coordination and an administrative assistant for deputy secretary Mark Heywood (Van der Linde 2008, Khumalo and Berger 2008:68). This funding stream circumvented the Resource Management Committee and the financial control of SANAC by the Minister of Health.

The financial difficulties within the women's sector reflected a lack of financial support for the entire civil society sector within SANAC. As such, the internal functioning of civil society sectors was also dependent on donor support and voluntary work by nonstate actors. The consultation process within the SANAC women's sector was initially supported by a grant from Oxfam. After this funding had been exhausted, internal consultation within this sector had been difficult to maintain. Janice described the cost associated with meetings that drew participants from across the country and the difficult process of coordinating schedules amongst the sectoral representatives and the extended reference group. Despite this tenuous financial support for SANAC and the civil society sectors, the policy development process continued on the basis of unpaid labour by non-state participants. 
A final factor that limited the impact of SANAC on HIV/ AIDS policy was the relationship between government funding and policy recommendations. Health budgeting in South Africa is tied to a three year planning mechanism called the medium term expenditure framework. Developed by the National Treasury, the expenditure framework offers government officials and foreign investors a degree of predictability in future funding allocations. The document was based upon projections developed at the start of each three year funding cycle. As such, funding for new policy initiatives such as the revised PMTCT guidelines was not guaranteed. The implementation of these guidelines only began in earnest after the departure of the Minister of Health in September 2008. At this point, the United Kingdom pledged $£ 15$ million near to support South Africa's new PMTCT policy and fund administrative support for SANAC (Watts 2008).

The institutional structure of both SANAC and the South African government played an important role in limiting the impact of consultative policy development. SANAC's role was to provide government with recommendations for policy and to provide oversight for the state and non-governmental HIV/AIDS response. In other words, the recommendations of the Council were not binding. Senior legal figures within the South African HIV/AIDS movement saw the recommendations of the body as enforceable through legal action via the Constitutional Court. However the point remains that SANAC was not able to directly change existing HIV/AIDS policy. This is an important factor to consider in South Africa's quasi-federal political system. In this structure, national institutions develop policy norms while provincial institutions implement policy (Friedman and Kihato 2004). As such, SANAC's position as an intermediary between the Presidency and the Department of Health was one that could only affect abstract policy norms rather than actual implementation strategies.

\section{Conclusion}

While operating within a context of political, economic and institutional constraint, SANAC guided the development of the most comprehensive public health response to the HIV/ AIDS epidemic in the world. This achieved the stated goal of the South African HIV/AIDS movement: to establish a rights- based public health response to the epidemic that included ART. Based upon the defined terms of the extended campaign for treatment access, SANAC's transformation is an undeniable success story. Based upon negotiation with - and direct action against - multinational corporations and political parties, a non-state social alliance transformed the capacity of the South African state to sustain life. This socio-political process offers a useful example to think through how contemporary conceptions of economy and society can be directed towards human needs.

An important factor to consider here is the role of international institutions, donor capital and transnational biomedical norms. The goals of the South African HIV/AIDS movement were aligned with transnational biomedical norms and policy guidelines from international institutions. While a campaign led by the TAC had transformed the international pricing system for HIV/AIDS drugs and changed transnational norms in the process - the orthodox biomedical understanding of the relationship between HIV and AIDS served as the backbone of the extended campaign for treatment access. This enabled a consistent flow of international donor capital to support the campaign in the context of AIDS dissidence. With the example of SANAC, the focus on national policy norms eventually led to the expansion of the state's public health response to the epidemic. As the development of PMTCT guidelines highlights, the shift to align with transnational norms did not focus on the first-hand knowledge of people infected and affected by HIV/AIDS. Rather, the process was driven by those with expertise in biomedicine and policy.

As such, an important question to address is extent to which these abstract norms reflect the life strategies and experiences of people living with HIV/AIDS in contemporary South Africa. Was this population able to participate in SANAC's policy development process in a substantive manner? Or do biomedical norms, the transnational donor capital associated with their dissemination and those who have expert knowledge of these fields of knowledge dominate the emergence of local forms of social organisation and/or responses to the social, material and political effects of the HIV/AIDS epidemic? While these questions cannot be answered here, the analysis of SANAC raises the importance of these issues for the analysis of consultative policy processes, institutional change and social change.

\section{References}

Altman, Denis. 2001. Global sex. Chicago: University of Chicago Press.

Baer, Hans; Merrill Singer and Ida Susser. 2003. Medical Anthropology and the World System. New York: Praeger.

Bond, Patrick. 2005. Elite transition: from apartheid to neoliberalism in South Africa. Scottsville: University of KwaZulu-Natal Press.

Chigwedere, Pride; George Seage III; Sofia Gruskin; Tun-Hou Lee; Myron Essex. 2008. Estimating the lost benefits of antiretroviral drug use in South Africa. Journal of Acquired Immune Deficiency Syndrome 49: 410-415.

Comaroff, Jean; John Comaroff. 2001. 'Millenial capitalism: first thoughts on a second coming,' in Millenial capitalism and the culture of neoliberalism. Edited by J. Comaroff and J. Comaroff, pp. 1 -56. Durham, NC: Duke University Press.

Deedat, Hameda; Eddie Cottle. 2002. 'Cost recovery and prepaid water meters: a case study in Madlebe, KZN,' in Cost recovery and the crisis of service delivery in South Africa. Edited by D. McDonald and J. Pape, pp.81 -100. New York: Zed Books.

Douglas, Mary. 1986. How institutions think. Syracuse, NY: Syracuse University Press.

Dumenil, Gerard; Dominic Levy. 2005. 'The neoliberal (counter-) revolution,' in Neoliberalism: a critical reader. Edited by A. Saad- Filho and D. Johnston, pp.9-20. Ann Arbor, MI: Pluto Press.

Durkheim, Emile; Marcel Mauss. 1963[ 1903]. Primitive classification. Translated by Rodney Needham. Chicago: University of Chicago Press.

Eisenstein, Hester. 2010. Feminism Seduced: how global elites use women's labor and ideas to exploit the world. Boulder, CO: Paradigm Publishers. Fassin, Didier. 2007. When bodies remember: experiences and politics of AIDS in South Africa. Berkeley: University of California Press.

Ferguson, James. 2006. Global shadows: Africa in the neoliberal world order. Durham: Duke University Press.

Friedman, Steven; Caroline Kihato. 2004. 'South Africa's double reform: decentralization and the transition from apartheid,' in Decentralization, Democratic Governance, and Civil Society in Comparative Perspective. Edited by P Oxhorn, J. Tulchin, and A. Selee, pp. 141-189. Washington, D.C.: Woodrow Wilson Press.

Geffen, Nathan. 2007. 'Policy, communications and research (PCR) report for period September to November 2007', in Treatment Action Campaign 4th 
national congress programmes report. Cape Town: Treatment Action Campaign, pp.81 -84.

Geffen, Nathan. 2010. Debunking delusions: the inside story of the Treatment Action Campaign. Johannesburg: Jacana.

Gevisser, Mark. 2007. Thabo Mbeki: the dream deferred. Johannesburg: Jonathan Ball.

Gilbert, Leah; Liz Walker. 2002. HIV/AIDS in South Africa: an overview. Cadernos de Sade Pblica 18(3):65 1 -60.

Gill, Lesley. 2000. Teetering on the rim: global restructuring, daily life and the armed retreat of the Bolivian state. New York: Columbia University Press.

Grebe, Eduard. 2011. The Treatment Action Campaign's struggle for AIDS treatment in South Africa: coalition-building through networks. Journal of Southern African Studies 37(4):849-868.

Hart, Keith. 2009. A human economy for the twenty-first century. Online: http://thememorybank.co.uk/2009/!1/30/a-human-economy-for-thetwenty-first-century/ [Accessed 1 August 2013]

Harvey, David. 2005. A brief history of neoliberalism. New Yark: Oxford University Press.

Heywood, Mark; Morna Cornell. 1998. Human rights and AIDS in South Africa: from right margin to left margin. Health and Human Rights 2(4):61 -82.

Hibou, Beatrice. 2004. 'Introduction: from privatising the economy to privatising the state,' in Privatizing the State. Edited by B. Hibou, pp. 1 -47. New York: Columbia University Press.

Karon, Tony. 2001. South African AIDS activist Zackie Achmat. Time Magazine April 14 2001. Online: http://www.time.com/time/ nation/article/0,8599, !06995,00.htm/ [Accessed 28 July 2013]

Khumalo, Nonkosi; Jonathan Berger. 2008. 'SANAC and the implementation of the NSP' in AlDS Law Project: !8-month review: July 2007 - December 2008. Edited by J. Berger, pp.6572. Johannesburg: Aids Law Project.

Makino, Kumiko. 2009. 'Institutional conditions for social movements to engage in formal politics: the case of AIDS activism in post-apartheid South Africa,' in Protest and Social Movements in the Developing World. Edited by S. Shigetomi and K. Makino, pp. 1 10-33. Northampton, MA: Edward Elgar.

McDonald, Greg; John Pape. 2002. 'Introdution,' in Cost recovery and the erisis of service delivery in South Africa. Edited by G. McDonald and J. Pape, pp. 1-16. New York: Zed Books.

Mitchell, Timothy. 2002. Rule of experts: Egypt, techno-politics, modernity. Berkeley: University of California Press.

Nattrass, Nicoli. 2007. Mortal combat: AIDS denialism and the struggle for antiretrovirals in South Africa. Scottsville: UKZN Press.

Nattrass, Nicoli. 2008. AIDS and the scientific governance of medicine in post-apartheid South Africa. African Affairs 107,427:157-176

Pitcher, J. Anne. 2012. Was privatisation necessary and how did it work? the case of South Africa. Review of African Political Economy 39(132):243260.

Polanyi, Karl. 2001 [1944]. The great transformation: the political and economic origins of our time. New York: Beacon Press.

Polanyi, Karl. 1977. The livelihood of man. Edited by Harry G. Pearson. New York: Academic Press.

Posel, Deborah. 2005. Sex, death and the fate of the nation: reflections on the politicization of sexuality in South Africa. Africa 75 (2): $125-153$.

Powers, Theodore. 2012. Institutionalizing dissent: HIV/AIDS, the post-apartheid state, and the limits of transnational governance in South Africa. Journal of Southern African Studies 38(3):53 1 -549

Powers, Theodore. 2013. Institutions, power and para-state political alliances: A critical reassessment of HIV/AIDS politics in South Africa, 19992008. Journal of Modern African Studies 51 (4)

Saul, John S. 2001. Millenial africa: capitalism, socialism, democracy. Trenton, NJ: Africa World Press.

Schneider, Helen. 2002. On the fault-line: the politics of AIDS policy in contemporary South Africa. African Studies 61(1): $145-167$.

Schneider, Jane; Ida Susser. 2003. 'Wounded cities: deconstruction and reconstruction in a globalized world,' in Wounded cities: deconstruction and reconstruction in a globalized world. Edited by J. Schneider and I. Susser, pp. 1 -24. New York: Berg.

Section 27. 2013. Staff and Board. Online: http://www.section27.org.za/staff-board/ [Accessed 7 August 2013]

Seekings, Jeremy; Nicoli Nattrass. 2005. Class, race and inequality in South Africa. New Haven: Yale University Press.

Soal, Judith. 2000. Rebels show smuggled drugs cost R100 less. IOL News. October 17, 2000.

Online: http://www.iol.co.za/news/south-africa/rebels-show-smuggled-drugs-cost-r 100-less-1.49696 [Accessed 28 July 2013]

Treatment Action Campaign. 2005. Joint civil society monitoring forum: monitoring The antiretroviral rollout.

Online: http:// www.tac.org.za/community/jcsmf [Accessed 22 June 2012]

UNAIDS. Joint United Nations Program on HIV/AIDS. 2013. Getting to zero: HIV/AIDS in eastern and southern Africa. Geneva: United Nations.

Van der Linde, Ina. 2008. HSRC receives Gates Foundation grant to support SANAC research sector. Human Sciences Research Council Media Briefs. Online: http://www.hsrc.ac.za/Media_Release-340.phtm/[Accessed 10 January 2013]

Watts, Susan. 2008. UK to give $£ 15 \mathrm{~m}$ fund S Africa Aids fight. BBC News. November 28, 2008.

Online: http://www.bbc.co.uk/blogs/ newsnight/susanwatts/2008/11/uk_to_give_15m_to_fund_s_afric. htm/[Accessed 15 January 2009] 